\title{
The Effect of Covid-19 Pandemic on the Adoption of Internet Banking in Indonesia: Islamic Bank and Conventional Bank
}

\author{
Heri SUDARSONO ${ }^{1}$, Rindang Nuri Isnaini NUGROHOWATI ${ }^{2}$, Yunice Karina TUMEWANG ${ }^{3}$ \\ Received: August 01, 2020 Revised: October 05, 2020 Accepted: October 15, 2020
}

\begin{abstract}
This study aims to examine the effect of perceived usefulness (PU), perceived ease of use (PEU), trust (TR), subjective norm (SN), and attitude (AT) on customer's Intention to Adopt Internet Banking (IAIB) at Islamic banks and conventional banks before and during the Covid-19 pandemic in Indonesia. The research model is based on the Theory of Planned Behavior (TPB) and the Technology Acceptance Model (TAM). This study involves 213 respondents for Islamic banks and 410 respondents for conventional banks from 25 provinces in Indonesia. Data was analyzed using partial least square (PLS) regression with the Structural Equation Model (SEM) method. The result of data analysis confirms several hypotheses taken from the literature. The results before the Covid-19 pandemic showed that AT and SN influence IAIB in Islamic banks. Whereas in conventional banks, AT, PU, SN, and TR influence IAIB. While during the Covid-19 pandemic, it shows that the AT, PU, IB, $\mathrm{SN}$, and customer TR influence IAIB in Islamic banks and conventional banks. From the analysis, it was found that the PEU variable did not have a significant effect on the intention of customers of Islamic banks and conventional banks to use Internet banking.
\end{abstract}

Keywords: Internet Banking, Islamic Bank, Conventional Bank, Technology Acceptance Model, Theory Planned Behavior

JEL Classification Code: M15, M31, M38

\section{Introduction}

Nowadays banking services are required to be more flexible, quicker, and easier along with the tremendous technology in the globalization era. Internet Banking (IB) has become the most profitable among other e-commerce applications. All banks have introduced IB to improve customer service and growth of information reduce costs (Rahi \& Abd-Ghani, 2019). Besides, IB will not only benefit banks but will also fulfill customer needs (Rahi \&

${ }^{1}$ First Author and Corresponding Author. Lecturer, Department of Economics, Faculty of Business and Economics, Universitas Islam Indonesia, Indonesia [Postal Address: Gedung Ace Partadiredja, Ring Road Utara, Condongcatur, Sleman, Yogyakarta, 55283, Indonesia] Email: heri.sudarsono@uii.ac.id

${ }^{2}$ Lecturer, Department of Economics, Faculty of Business and Economics, Universitas Islam Indonesia, Indonesia.

Email: rindangnuri@uii.ac.id

${ }^{3}$ Lecturer, Department of Accounting, Faculty of Business and Economics, Universitas Islam Indonesia, Indonesia.

Email: yunice.karina@uii.ac.id

(c) Copyright: The Author(s)

This is an Open Access article distributed under the terms of the Creative Commons Attribution Non-Commercial License (https://creativecommons.org/licenses/by-nc/4.0/) which permits unrestricted non-commercial use, distribution, and reproduction in any medium, provided the original work is properly cited.
Abd-Ghani, 2016; Shahzad et al., 2017). The tremendous growth of the Internet is changing how a business stays connected with its customers, including the banking business (Aldás-Manzano et al., 2009). The survival of the financial industry, especially banking, will greatly depend on the ability of Internet adaptation and the progress of technology. One form of technology adaptation in the banking industry is IB and mobile banking which offer various benefits (Sitorus et al., 2017).

Adaptation of banking technology must at least offer services that support customer activities, offer relevant markets, provide benefits for customers, as well as accessible and easy to use (Tabash et al., 2019; Yudha et al., 2015). Customers are encouraged to use Internet services because there is no need to have a physical meeting with the bank officers in person and no need to deal with other customers. The same thing was expressed by Kaleem \& Ahmad (2010) in their research which found that IB was used to reduce inconvenience, transaction costs, and time consumed. Because of the ease of obtaining information and many other benefits, the use of an online financial system is increasing (Lech, 2012). By replacing employee functions and physical facilities with information technology, banks do not need to have branch offices to reduce operating and fixed costs. 
Although IB offers various facilities, banking in Indonesia still faces a problem in form of a low adoption rate (Sitorus et al., 2017). Some research results show that the perception of ease of use, security, and benefit contribute a significant influence on the adoption of IB in Indonesia (Asni et al., 2019; Ronny, 2018). The successful use of IB depends on how the customer understands the system. Thus, banks need to find out how customers accept IB services to help find strategic plans and improve the markets (Fatimah \& Suyanto, 2016). However, banks still have problems related to the low willingness of customers to adopt IB regardless of its benefits (Rahi \& Abd-Ghani, 2019). Besides, banks are required to provide high-quality Internet facilities to attract and retain customers (Makanyeza \& Chikazhe, 2017; Sharma et al., 2020).

\section{Literatur Review}

\subsection{Theoretical Background}

The Technology Acceptance Model (TAM) is the mostadopted theory to examine the individual's belief in the acceptance and the use of technology. This is because this theory focuses on the use of information systems originated from the research to validate the acceptance of IBM workers toward the word processing technology conducted by (Davis et al., 1989). In general, TAM has been used in various crosssector studies including personal computers, telemedicine technology, the World Wide Web (www), and e-commerce. Specifically, in the context of banking technology, several studies such as Abbad (2013) and Martins et al. (2014) have applied TAM to examine the acceptance and the use of ATMs, mobile banking, and IB.

In a study that applied the Theory of Planned Behavior (TPB), Bhatt (2011) examined customer trust (TR) in IB services and found that customer intention to adopt IB was influenced by perceived behavioral control, customer attitude (AT), and subjective norm (SN). By modifying TAM, Kesharwani \& Tripathy (2012) proved that self-efficacy and perceived risk contribute a significant impact on the behavior of using IB. Following that, Varaprasad et al. (2013) also add several variables such as perceived risk, relative advantage, and attention. It is found that perceived usefulness (PU), perceived ease of use (PEU), perceived risk, and relative advantage are important factors in determining IB adoption. With the TAM modification theory, Kesharwani \& Tripathy (2012) also found that PEU, PU, perceived risk, and social influence have a significant positive impact on customer intention in adopting IB services (Kalaiarasi \& Srividya, 2013).

The purpose of this study is to determine the variables that influence the use of IB in Islamic and conventional banks before and during the Covid-19 pandemic in Indonesia. This study also modified TAM and perceived behavioral control (PBC) by adding several variables and considering the compatibility with

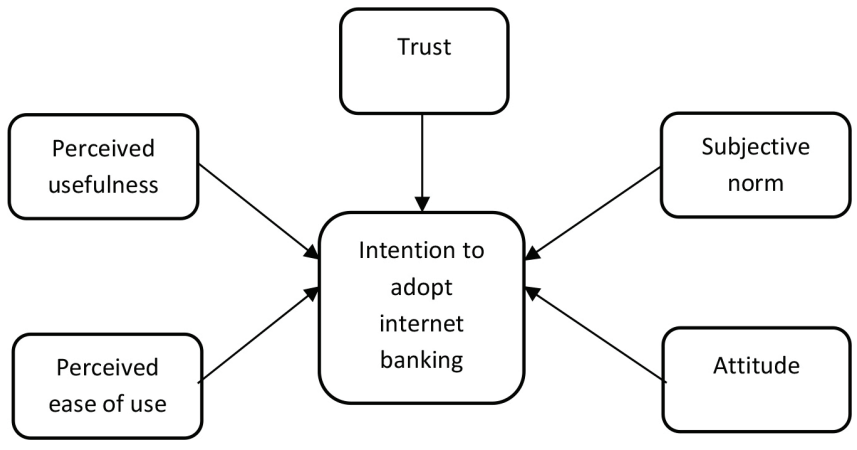

Figure 1: Research Model

the problems that occur in Islamic and conventional banks. Besides, this study also considers changes in behavior that occurred before and during the Covid-19 pandemic that began in February 2020 in Indonesia. Figure 1 shows the research model proposed in this study which consists of five constructs such as PU, PEU, TR, SN, and AT. The combination of TAM and $\mathrm{PBC}$ is expected to describe the customer intention of Islamic and conventional banks in the adoption of IB.

\subsection{Perceived Usefulness (PU)}

PU can be defined as the extent to which customers believe that the use of IB service will improve their banking performance or activities (Bashir \& Madhavaiah, 2014). Many researchers in the field of information systems (IS) showed the positive impact of PU on AT and intention to adopt IB using TAM (Heryani et al., 2020). Besides, some previous studies on IB have provided empirical evidence that PU has a significant positive effect on AT and intention (Kaur \& Malik, 2019; Vukovic et al., 2019). Previous research has also proven that PU could mediate the effect of external factors on AT and intention. Hence, a customer will be more inclined to adopt IB when one considers the use of IB to bring benefits. Based on this review, the proposed hypothesis is as follows:

H1: Perceived usefulness has a significant influence on customer interest to adopt IB

\subsection{Perceived Ease of Use (PEU)}

PEU can be defined as the level of customer confidence that the use of IB service is easy (Baber, 2019; Davis et al., 1989). PEU is the main factor influencing customer intention to adopt IB. Several existing literature reveals that PEU affects an individual's intention to use IB (Davis et al., 1989; Kaur \& Malik, 2019). Several studies on the use of IB have found that PEU influences customer intention to use IB (Giovanis et al., 2012; Vukovic et al., 2019). 
Besides, several studies have found that PEU of IB will enhance customer intention to use various transactions (Abbad, 2013). Customers find it easy to use IB if the IB menu is uncomplicated, easy to remember, and based on the customer needs (Alalwan et al., 2018; Kesharwani $\&$ Tripathy, 2012). Based on the previous literature, the proposed hypothesis is as follows:

H2: Perceived ease of use has a significant influence on customer interest to adopt IB

\subsection{Trust (TR)}

TR is defined as the customer's confidence in the ability of IB services to provide services as expected (Bashir \& Madhavaiah, 2014). TR is an important factor in providing confidence to fulfill customer needs (Morgan \& Hunt, 1994; Usman, 2015). TR holds a crucial role in minimizing risk in the case of conflict between banks and customers (Gefen et al., 2015). Risk and TR are two elements that could not be separated in the decisionmaking process (Aldás-Manzano et al., 2009; Kesharwani \& Tripathy, 2012). Further, bad technology will increase the risk that causes a decrease in the level of satisfaction and willingness of customers to use IB (Yuan et al., 2016). From this explanation, the hypothesis can be proposed as follows:

H3: Trust has a significant influence on customer interest to adopt IB

\subsection{Subjective Norm (SN)}

$\mathrm{SN}$ is referred to as the normative belief of the social environment that motivates an individual to perform a certain behavior. This aspect specifically applies to social pressures which come from important people considered by an individual (Fishbein \& Ajzen, 1975). Chan (2001) found that social pressure plays a crucial role in describing the adoption of the Internet which has been a widely discussed topic. Some researchers emphasize that $\mathrm{SN}$ is a factor that needs to be taken into account for influencing individual AT (Taib et al., 2008). In the study of Liao et al. (2007), they found that SN affects the customer's intention to adopt IB. On the other hand, several researchers such as Lada et al., (2009) found a direct effect of SN on the intention to consume halal products. Therefore, the hypothesis can be formulated as follows:

H4: Subjective norm has a significant influence on customer interest to adopt IB

\subsection{Attitude (AT)}

AT could be described as a tendency to consistently respond in connection with a particular object (Fishbein \&
Ajzen, 1975). In this study, AT could be described as positive or negative feelings of customers in using IB services. Fishbein \& Ajzen (1975) is the earliest study that introduced AT in TRA which was then followed by Davis (1989), who stated that AT is a construct in TAM which ultimately affects individual intention. AT becomes an inseparable factor in the context of IB because the AT is formed by the customer's belief in risk and security in using IB. The previous researches conducted by Chiou \& Shen (2012) and Kaur \& Malik (2019) provide evidence that customer AT influences the intention to adopt IB services. Based on the above explanation, the proposed hypothesis is as follows:

H5: Attitude has a significant influence on customer interest to adopt IB.

\section{Research Method}

\subsection{Procedure and Sample}

For data collection, this study distributed a structured questionnaire comprising three parts, to IB users in Indonesia. The first part is designed to gather data pertaining to the respondent's demographic background which are gender, religion, age, education, occupation, marital status, income, and bank account. The second part of the questionnaire asked the respondent's interest in using IB before the Covid-19 pandemic. The third part of the questionnaire asked the respondent's interest in using IB during the Covid-19 pandemic.

The second and the third part is designed to be the measurement instrument adapted from the previous literature related to the model of technology utilization and their development in the context of using several technologies in general and IB technology in particular. A list of 23 questions in 6 constructs is included in the conceptual model including PU, the PEU, customer TR, SN, and customer AT. All items are measured on a Likert-type scale ranging from "1" (strongly disagree) to " 5 " (strongly agree).

Before commencing the core data collection process, a pilot test was conducted to test the instrument items on a sample of 50 respondents, to measure the required time to fill out the questionnaire and to obtain a comprehensive understanding of the respondents' difficulties in answering each question. The result of this pilot test caused some changes to a few words to make it easier for respondents to answer each construct's question.

The analysis is performed using a Partial Least SquareStructural Equation Model (PLS-SEM) technique by SmartPLS software (Ringle et al., 2015). The advantage of this technique is that it could use abnormal data and explain the differences between the target constructs. PLS-SEM is a two-step process in which the first measurement model 
is analyzed to check the reliability and validity of the data. Second, an assessment of the structural model is carried out for path analysis and hypothesis testing.

\subsection{Sample Descriptive}

The respondents consist of 213 Islamic bank customers and 410 Conventional bank customers in 34 Provinces in Indonesia. Islamic banks' customers are $39.44 \%$ of men and $60.56 \%$ of women, in which $78.87 \%$ of them are $18-25$ years old. Meanwhile, for the monthly expenditure, $66.67 \%$ of the respondents are spending less than IDR 2,500,000 and $23.00 \%$ of them are spending IDR 2,600,000 - IDR $5,000,000$. For the educational background, $68.08 \%$ of the respondents are having a high school degree and
$23.94 \%$ of them are having an undergraduate degree. For the occupation, the majority of respondents (74.18 percent) are students and $14.08 \%$ of them are private employees.

Meanwhile, conventional bank respondents consist of 166 men (40.49\%) and 244 women (59.51\%), while $78.29 \%$ of them are $18-25$ years old and $10.24 \%$ of them are $26-35$ years old. For the monthly expenditure, $63.66 \%$ of the respondents are spending less than IDR 2,500,000 and $25.66 \%$ of them are spending IDR 2,600,000 - IDR 5,000,000. For the educational background, $68.29 \%$ of the respondents are having a high school degree and $23.17 \%$ of them are having an undergraduate degree. For the occupation, the majority of respondents $(66.10 \%)$ are students and $18.54 \%$ of them are private employees.

Table 1: Demographic Characteristics of the Sample

\begin{tabular}{|c|c|c|c|c|c|}
\hline \multirow{2}{*}{ Demography } & \multirow{2}{*}{ Notes } & \multicolumn{2}{|c|}{$\begin{array}{c}\text { Islamic Bank } \\
\text { (213 Respondents) }\end{array}$} & \multicolumn{2}{|c|}{$\begin{array}{l}\text { Conventional Bank } \\
\text { (410 Respondents) }\end{array}$} \\
\hline & & $\mathbf{N}$ & $\%$ & $\mathbf{N}$ & $\%$ \\
\hline \multirow{2}{*}{ Gender } & Man & 84 & 39.44 & 166 & 40.49 \\
\hline & Woman & 129 & 60.56 & 244 & 59.51 \\
\hline \multirow{4}{*}{ Age } & $18-25$ years old & 168 & 78.87 & 321 & 78.29 \\
\hline & $26-35$ years old & 22 & 10.33 & 42 & 10.24 \\
\hline & $36-45$ years old & 13 & 6.10 & 18 & 4.39 \\
\hline & $46-55$ years old & 10 & 4.69 & 25 & 6.10 \\
\hline \multirow{6}{*}{ Expense } & $<$ Rp 2.500.000- & 142 & 66.67 & 261 & 63.66 \\
\hline & Rp 2.600.000 - Rp 5.000.000 & 49 & 23.00 & 104 & 25.37 \\
\hline & Rp 5.100.000 - Rp 7.500.000 & 9 & 4.23 & 19 & 4.63 \\
\hline & Rp 7.600.000 - Rp 10.000.000 & 3 & 1.41 & 8 & 1.95 \\
\hline & Rp 10.100.000 - Rp 12.500 .000 & 2 & 0.94 & 5 & 1.22 \\
\hline & $>\operatorname{Rp} 12.600 .000$ & 9 & 4.23 & 13 & 3.17 \\
\hline \multirow{5}{*}{ Latest Education } & Senior High School and equivalent & 145 & 68.08 & 280 & 68.29 \\
\hline & Diploma (D3) & 3 & 1.41 & 15 & 3.66 \\
\hline & Bachelor(S1) & 51 & 23.94 & 95 & 23.17 \\
\hline & Master (S2) & 12 & 5.63 & 20 & 4.88 \\
\hline & Doctor (S3) & 2 & 0.94 & 0 & 0.00 \\
\hline \multirow{5}{*}{ Occupation } & Student & 158 & 74.18 & 271 & 66.10 \\
\hline & Civil Officers & 11 & 5.16 & 29 & 7.07 \\
\hline & Private Employee & 30 & 14.08 & 76 & 18.54 \\
\hline & Entrepreneur & 7 & 3.29 & 21 & 5.12 \\
\hline & Housewife & 7 & 3.29 & 13 & 3.17 \\
\hline
\end{tabular}




\section{Results}

\subsection{Confirmatory Factor Analysis, Reliability, and Validity}

The loading factor of all constructs is above 0.6 which shows adequate convergent validity among all latent variables (Chin, 1998). In Table 2, the result of loading factors of Islamic and conventional banks before and during the Covid-19 pandemic shows that the perceived risk was below 0.6. Although some other literature explains that the lowest loading factor that can be accepted is 0.40 , a high loading factor indicates a high data variations which will make a strong contribution to explain the latent construction.

Table 2: Loading Factor Before and During Covid-19 Pandemic

\begin{tabular}{|c|c|c|c|c|c|}
\hline \multirow{2}{*}{ Construct } & \multirow{2}{*}{ Item } & \multicolumn{2}{|c|}{ Before Covid 19} & \multicolumn{2}{|c|}{ During Covid 19} \\
\hline & & ISB & CB & ISB & CB \\
\hline \multirow{4}{*}{$\begin{array}{l}\text { Perceived } \\
\text { Usefulness } \\
\text { (PU) }\end{array}$} & $\begin{array}{l}\text { The use of IB improves the functions of my banking } \\
\text { activity }\end{array}$ & 0.873 & 0.838 & 0.92 & 0.85 \\
\hline & $\begin{array}{l}\text { IB enables me to manage my banking activity more } \\
\text { efficiently }\end{array}$ & 0.912 & 0.862 & 0.866 & 0.872 \\
\hline & IB enables me to do my banking activity comfortably & 0.926 & 0.909 & 0.928 & 0.923 \\
\hline & IB enables me to do my banking activity quickly & 0.892 & 0.837 & 0.913 & 0.912 \\
\hline \multirow{4}{*}{$\begin{array}{l}\text { Perceived } \\
\text { Ease of Use } \\
\text { (PEU) }\end{array}$} & It is very easy to use IB & 0.898 & 0.86 & 0.896 & 0.902 \\
\hline & Learning to use IB is easy & 0.935 & 0.896 & 0.944 & 0.891 \\
\hline & $\begin{array}{l}\text { Instruction provided on the IB website is clear and } \\
\text { understandable }\end{array}$ & 0.918 & 0.886 & 0.903 & 0.915 \\
\hline & I feel that it is easy to remember how to use IB & 0.935 & 0.893 & 0.928 & 0.92 \\
\hline \multirow{4}{*}{ Trust (TR) } & $\begin{array}{l}\text { I believe that it is always safe to transfer money } \\
\text { using IB }\end{array}$ & 0.85 & 0.857 & 0.89 & 0.861 \\
\hline & I believe I can count on transferring money using IB & 0.912 & 0.856 & 0.875 & 0.889 \\
\hline & $\begin{array}{l}\text { My bank immediately notifies me if there are problems } \\
\text { with my transaction }\end{array}$ & 0.774 & 0.706 & 0.807 & 0.751 \\
\hline & $\begin{array}{l}\text { I believe that my transaction through IB will always be } \\
\text { transparent }\end{array}$ & 0.857 & 0.825 & 0.851 & 0.894 \\
\hline \multirow{3}{*}{$\begin{array}{l}\text { Subjective } \\
\text { Norm (SN) }\end{array}$} & $\begin{array}{l}\text { Most of the people who are important to me would } \\
\text { think that I should use IB }\end{array}$ & 0.867 & 0.895 & 0.925 & 0.941 \\
\hline & $\begin{array}{l}\text { People who influenced me would think that I should } \\
\text { use IB }\end{array}$ & 0.892 & 0.874 & 0.935 & 0.951 \\
\hline & $\begin{array}{l}\text { People whose opinions I value would think I should } \\
\text { use IB }\end{array}$ & 0.894 & 0.881 & 0.93 & 0.94 \\
\hline \multirow{4}{*}{ Attitude (AT) } & Using IB service is a good decision & 0.931 & 0.912 & 0.933 & 0.924 \\
\hline & Using IB service is a wise decision & 0.93 & 0.885 & 0.934 & 0.935 \\
\hline & Using IB service is a positive move & 0.915 & 0.909 & 0.953 & 0.932 \\
\hline & I like to use IB service & 0.869 & 0.878 & 0.889 & 0.884 \\
\hline \multirow{4}{*}{$\begin{array}{l}\text { Intention } \\
\text { to Adopt } \\
\text { Internet } \\
\text { Banking } \\
\text { (IAIB) }\end{array}$} & $\begin{array}{l}\text { I intend to enhance the use of my IB service in the } \\
\text { future }\end{array}$ & 0.893 & 0.869 & 0.915 & 0.899 \\
\hline & $\begin{array}{l}\text { I hope my transaction through IB will be enhanced in } \\
\text { the future }\end{array}$ & 0.858 & 0.845 & 0.902 & 0.884 \\
\hline & $\begin{array}{l}\text { I will encourage my friends and family to use IB } \\
\text { service }\end{array}$ & 0.904 & 0.887 & 0.9 & 0.911 \\
\hline & I would highly recommend others to use IB & 0.904 & 0.848 & 0.923 & 0.91 \\
\hline
\end{tabular}

Note: ISB, Islamic bank; CB, Conventional Bank. 
Meanwhile, internal consistency between items or reliability is measured using Cronbach's $\alpha$, rho A and Composite Reliability. Any value of Cronbach's $\alpha$, rho A and Composite Reliability which are higher than 0.7 is considered to have good internal consistency (Hair et al., 1994). From Table 3, it shows that the Cronbach's $\alpha$ value for all items is more than
0.7 or can be categorized as reliable. Meanwhile, the values of rho A and composite reliability are also higher than 0.7 , which means that all constructs of Islamic and conventional banks before and during the Covid pandemic are reliable. Meanwhile, the Average Variance Extracted (AVE) for a construct must be higher than 0.50 (Fornell \& Larcker, 1981).

Table 3: Cronbach's Alpha, Composite Reliability and Average Variable Extracted (AVE)

\begin{tabular}{|c|c|c|c|c|}
\hline & CA & rho_A & CR & AVE \\
\hline \multicolumn{5}{|c|}{ ISB before Covid-19 pandemic } \\
\hline AT & 0.932 & 0.933 & 0.952 & 0.831 \\
\hline IAIB & 0.913 & 0.914 & 0.939 & 0.792 \\
\hline PEU & 0.941 & 0.941 & 0.958 & 0.849 \\
\hline PU & 0.923 & 0.925 & 0.945 & 0.812 \\
\hline SN & 0.861 & 0.863 & 0.915 & 0.782 \\
\hline TR & 0.871 & 0.878 & 0.912 & 0.722 \\
\hline \multicolumn{5}{|c|}{ CB before Covid-19 pandemic } \\
\hline AT & 0.918 & 0.920 & 0.942 & 0.803 \\
\hline IAIB & 0.885 & 0.886 & 0.921 & 0.744 \\
\hline PEU & 0.907 & 0.907 & 0.935 & 0.782 \\
\hline PU & 0.884 & 0.887 & 0.920 & 0.743 \\
\hline SN & 0.860 & 0.863 & 0.914 & 0.780 \\
\hline TR & 0.828 & 0.840 & 0.886 & 0.662 \\
\hline \multicolumn{5}{|c|}{ ISB during Covid-19 pandemic } \\
\hline AT & 0.946 & 0.947 & 0.961 & 0.861 \\
\hline IAIB & 0.931 & 0.932 & 0.951 & 0.828 \\
\hline PEU & 0.938 & 0.940 & 0.955 & 0.843 \\
\hline PU & 0.928 & 0.931 & 0.949 & 0.823 \\
\hline SN & 0.922 & 0.923 & 0.951 & 0.865 \\
\hline TR & 0.878 & 0.879 & 0.916 & 0.733 \\
\hline \multicolumn{5}{|c|}{ CB during Covid-19 pandemic } \\
\hline AT & 0.938 & 0.939 & 0.956 & 0.844 \\
\hline IAIB & 0.923 & 0.924 & 0.945 & 0.812 \\
\hline PEU & 0.928 & 0.931 & 0.949 & 0.823 \\
\hline $\mathrm{PU}$ & 0.912 & 0.915 & 0.938 & 0.792 \\
\hline $\mathrm{SN}$ & 0.939 & 0.941 & 0.961 & 0.892 \\
\hline TR & 0.871 & 0.882 & 0.913 & 0.724 \\
\hline
\end{tabular}

Note: CA, Cronbach's Alpha; CR, Composite Reliability; AVE, Average Variance Extracted. 


\subsection{Analysis of Model Structure and Hypothesis Testing}

After fulfilling the reliability and validity requirements, the data is tested to determine the model fit. To test the goodness of fit statistics of the model, the most commonly used measurements are SRMR, d_ULS, d_G, Chi-Square, and Normative Fit Index (NFI). Standardized Root Mean Square Residual (SRMR) is used as a measure of goodness of fit to avoid the model specification errors (Henseler et al., 2014). SRMR is defined as the difference between observed and expected correlations in the model and it is used as an absolute measure of the matching criteria. The model is considered goodness of fit when the SRMR value is less than 0.10 or 0.08 (Hu \& Bentler, 1998). From the test results, it is found that the SRMR value for Islamic banks before Covid-19 is 0.047 , and for conventional banks is 0.049 . Meanwhile, during the Covid-19 pandemic, it is found that the SRMR value is 0.050 for Islamic banks and 0.045 for conventional banks. As the value is less than 0.08 , it can be said that the model is considered suitable or model fit.

Model fit d_ULS (ie, the squared Euclidean distance) and d_G (ie, the geodesic distance) are bootstrap-based inferential statistics testing to measure the difference between the empirical covariance matrix and covariance matrix implied in the composite factor model (Dijkstra \& Henseler, 2015). The criteria for the model fit of d_ULS and d_G are that the differences between the correlation matrix implied by the model and the empirical correlation matrix must be insignificant ( $p>0.05)$. Conversely, if the difference is significant $(p<0.05)$, the model fit is not fulfilled. From the measurement, it was concluded that the model fit was fulfilled because the values of d_ULS and d_G of Islamic and conventional banks before Covid and during Covid are higher than 0.05 or not significant. The test results before Covid-19 show d_ULS $=0.612 ; \mathrm{d} \_\mathrm{G}=0.518$ for Islamic banks and $\mathrm{d}_{-}$

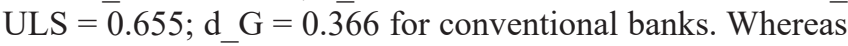
during Covid- 19 , the test results show d_ULS $=0.687$; d_G $=0.677$ for Islamic banks and d_ULS $=0.570 ;$ d_G $=0 . \overline{429}$ for conventional banks.

Normed Fit Index (NFI) is obtained by deducting 1 with the value of $\mathrm{Chi}^{2}$ from the proposed model divided by the value of $\mathrm{Chi}^{2}$ from the zero model. The NFI value ranges from 0 to 1 . The model can be said to be fit when the NFI value approaches the value of 1 (Lomoller, 1989). From Table 4, it can be seen that the NFI values of Islamic and conventional banks before and during Covid-19 are close to 1 to have an acceptable model fit. For Islamic banks, the NFI values before and during Covid-19 are 0.868 and 0.854 respectively. For conventional banks, the NFI values before and during Covid-19 are 0.871 and 0.892 .

The next model fit is adjusted $\mathrm{R}^{2}$ which illustrates the ability of explanatory variables in measuring the customer intention to adopt IB. The value of $\mathrm{R}^{2}$ for Islamic banks before Covid is 0, 729 which means that the ability of explanatory variables in measuring customer intention to adopt IB is $72.9 \%$. Meanwhile, the value of $\mathrm{R}^{2}$ of Islamic banks during Covid is 0.798 which means that the ability of explanatory variables in explaining customer intention to adopt IB is $79.8 \%$. Meanwhile, for conventional banks, the value of $\mathrm{R}^{2}$ before Covid is 0.614 which means that the ability of explanatory variables in explaining the customer intention to adopt IB is $61.4 \%$ t. For the conventional bank, the value of $\mathrm{R}^{2}$ during Covid-19 is 0.689 which means that the ability of explanatory variables in explaining customer intention to adopt IB is $68.9 \%$.

From the results of hypothesis testing for Islamic banks before the Covid-19 pandemic, it shows that AT $(B=0.494$, $\mathrm{t}$-stat $=7.164)$ and $\mathrm{SN}(\beta=0.223$, $\mathrm{t}$-stat $=3,730)$ have an effect on the customer intention to adopt IB, while PU, perceived risk, PEU and TR have no effect. Meanwhile for conventional banks before the Covid-19 pandemic, it shows that AT, $(\beta=0.516$, t-stat $=8,664), \mathrm{PU}(\beta=0.139$, t-stat $=$ 2.137), SN $(\beta=0.167$, t-stat $=3,647)$ and TR $(\beta=0,120$, t-stat $=2,058$ ) have an effect on the customer intention to adopt IB, while PEU and perceived risk have no effect.

From the results of hypothesis testing for Islamic banks during the Covid-19 pandemic, it shows that $(\beta=0.422$, t-stat $=5.888), \mathrm{PU}(\beta=0.206$, t-stat $=2.380)$, and $\mathrm{SN}(\beta=0.259$, t-stat $=4,460$ ) have an effect on the customer intention to adopt IB, while PEU, perceived risk and TR have no effect. Meanwhile for conventional banks during the Covid-19 pandemic, it shows that AT $(\beta=0.362$, t-stat $=4.678)$, PU $(\beta=0.180$, t-stat $=2.459)$, and SN $(\beta=0.264$ t- stat $=4,467)$ have an effect on the customer intention to adopt IB, while PEU and perceived risk have no effect.

Table 4: Fit Model

\begin{tabular}{|l|c|c|c|c|c|c|}
\hline & SRMR & d_ULS & d_G & Chi-Square & NFI & Adj R \\
\hline ISB before Covid-19 pandemic & 0.047 & 0.612 & 0.518 & 655.089 & 0.868 & 0.729 \\
\hline CB before Covid-19 pandemic & 0.049 & 0.655 & 0.366 & 919.664 & 0.871 & 0.614 \\
\hline ISB during Covid-19 pandemic & 0.050 & 0.687 & 0.677 & 847.640 & 0.854 & 0.798 \\
\hline CB during Covid-19 pandemic & 0.045 & 0.570 & 0.429 & $1,053.221$ & 0.892 & 0.689 \\
\hline
\end{tabular}


Table 5: Hypothesis Test

\begin{tabular}{|c|c|c|c|c|c|}
\hline & $\begin{array}{l}\text { Sample Mean } \\
\text { (M) }\end{array}$ & $\begin{array}{l}\text { Standard } \\
\text { Deviation }\end{array}$ & T Statistics & P Values & Result \\
\hline \multicolumn{6}{|c|}{ ISB before Covid-19 pandemic } \\
\hline AT -> IAIB & 0.494 & 0.070 & 7.164 & 0.000 & Supported \\
\hline PEU-> IAIB & 0.092 & 0.073 & 1.263 & 0.207 & Not supported \\
\hline PU -> IAIB & 0.106 & 0.072 & 1.403 & 0.161 & Not supported \\
\hline SN -> IAIB & 0.223 & 0.059 & 3.730 & 0.000 & Supported \\
\hline TR $->$ IAIB & 0.055 & 0.070 & 0.830 & 0.407 & Not supported \\
\hline \multicolumn{6}{|c|}{ CB before Covid-19 pandemic } \\
\hline AT $->$ IAIB & 0.516 & 0.060 & 8.664 & 0.000 & Supported \\
\hline PEU-> IAIB & -0.027 & 0.060 & 0.440 & 0.660 & Not supported \\
\hline PU -> IAIB & 0.139 & 0.066 & 2.137 & 0.033 & Supported \\
\hline SN -> IAIB & 0.167 & 0.046 & 3.647 & 0.000 & Supported \\
\hline TR $->$ IAIB & 0.120 & 0.057 & 2.058 & 0.040 & Supported \\
\hline \multicolumn{6}{|c|}{ ISB during Covid-19 pandemic } \\
\hline AT $->$ IAIB & 0.422 & 0.071 & 5.888 & 0.000 & Supported \\
\hline PEU-> IAIB & 0.116 & 0.081 & 1.403 & 0.161 & Not supported \\
\hline PU -> IAIB & 0.206 & 0.088 & 2.380 & 0.018 & Supported \\
\hline SN -> IAIB & 0.259 & 0.059 & 4.460 & 0.000 & Supported \\
\hline TR $\rightarrow>$ IAIB & -0.004 & 0.063 & 0.034 & 0.973 & Not supported \\
\hline \multicolumn{6}{|c|}{ CB during Covid-19 pandemic } \\
\hline AT $->$ IAIB & 0.362 & 0.077 & 4.678 & 0.000 & Supported \\
\hline PEU-> IAIB & 0.063 & 0.062 & 1.007 & 0.314 & Not supported \\
\hline PU -> IAIB & 0.180 & 0.075 & 2.459 & 0.014 & Supported \\
\hline SN -> IAIB & 0.264 & 0.060 & 4.467 & 0.000 & Supported \\
\hline TR $\rightarrow>$ IAIB & 0.081 & 0.076 & 0.992 & 0.322 & Not supported \\
\hline
\end{tabular}

\section{Discussion}

This study attempts to understand the customer intention to adopt IB in Indonesia before and during the Covid-19 pandemic by integrating two theories which are TPB and TAM. The result shows that before and during the Covid-19 pandemic, AT of Islamic and conventional banks has a significant positive effect on customer intention to adopt IB. These results are consistent with the research of Chiou \& Shen (2012) who reveal that AT determines the customer's intention to adopt IB.

Meanwhile, PEU in Islamic and conventional banks before and during the Covid-19 have no significant positive effect on customer intention to adopt IB. These results contradict the original TAM model and other research findings such as (Chau \& Ngai, 2010) and (Giovanis et al., 2012). These results indicate that before and during the Covid-19 pandemic, the customers of Islamic and conventional banks found it difficult to use IB.

PU of conventional banks before and during the Covid-19 pandemic is found to have a significant positive effect on customer intention to adopt IB. This finding is similar to the original TAM model and consistent with the research of (Heryani et al., 2020). On the other hand, PU of Islamic banks have a significant effect on the use of IB during Covid-19, but no significant effect before that. This shows that Islamic bank customers feel more benefits from IB during the Covid-19 pandemic, compared to before the Covid-19 pandemic. This is consistent with the research of Chiou \& Shen (2012; Kaur \& Malik (2019), and Vukovic et al. (2019). SN in Islamic and conventional banks before and during the Covid-19 pandemic significantly influenced the customer intention to adopt IB. 
From these results, it can be said that the people closest to the customer environment also influence the intention of Islamic and conventional bank customers to use IB. However, the result is not in line with the research conducted by Kholid (2019), which found that social factors or the influence of the closest people do not affect the intention of millennial customers in using digital banks.

Customer TR of Islamic banks before the Covid-19 pandemic did not affect the customer's intention to adopt IB. Likewise, during the Covid-19 pandemic, customer TR of Islamic and conventional banks do not affect the use of IB. Meanwhile, conventional banks before the Covid-19 pandemic shows that TR influenced the customer intention to adopt IB. This result is supported by the research of (Sharma et al., 2020). This shows that the Covid-19 pandemic reduced customer confidence in Islamic and conventional banks to use IB.

\section{Managerial Implications}

IB is utilized by customers to make it easier to meet the needs of customers and banks (Simintiras et al., 2014; Sitorus et al., 2017). A study revealed that respondents who are mostly young generation have the potential to utilize IB (Dwivedi \& Irani, 2009). The dynamic character of young people requires the management of banks to implement effective marketing strategies to increase the use of IB by customers (Meuter et al., 2005). As most of the young people are students who can use the Internet, it is not difficult for them to utilize the IB facilities provided by banks (Alalwan et al., 2018). IB facilities could not only help the customer in term of business transactions but also help them to save time and energy (Gumussoy, 2016)

Indonesian banks can also use social media to conduct socialization in a more persuasive, advanced, and economic way. Indeed, social media like YouTube, Facebook, and Twitter show a higher level of accessibility because everyone can easily access this application. (Berthon et al., 2012). As per a research in January 2020, there are ten main social media platforms in Indonesia which are Youtube (132 million users), Whatsapp 125 million users), Facebook (122 million users), Instagram (120 million users), Line (89 million users), Twitter (78 million users) million), FB Messenger (71 million users), BBM (57 million users), Linkedin (50 million users), and Pinterest (4 million users) (We are Social, 2020). This fact shows that social media has been used by all Indonesian people in 2020. Thus, using social media applications to promote the adoption of IB will help Indonesian banking to reach more banking customers. This shows that the use of the Internet to help customers is an inseparable part of the demands of modern human life that wants everything to be fast, cheap, and easy (Rahi \& Abd. Ghani, 2019).
Problems experienced by customers of Islamic and conventional banks during the Covid-19 pandemic are the difficulties faced in using IB. Thus, bank management should not merely facilitate customers with IB, but also facilitate customers to be willing and able to use IB (Chen \& Zhou, 2016). Banks must improve the facilities needed to optimize the use of IB. For this reason, IB should not only provide online banking facilities but also simplify online access, provide a variety of menus to suit customer needs, and launch more attractive features. (Kaur \& Malik, 2019). Initially, banks need to concentrate on providing IB channels compatible with other common technologies used by customers. At the same time, banks need to convince them that using these channels is not much different from other technologies (Vukovic et al., 2019).

\section{Conclusions}

The data for this study consisted of 213 Islamic bank customers and 410 Conventional bank customers. The findings show that this research successfully predicted the intention of customers to use IB. The results show that all TPB constructions (AT and SN) significantly predicted customer intention in Islamic and conventional banks before and during the Covid-19 pandemic. In the case of the TAM construct, it was identified that the PEU is not found to have a significant effect on the intention of customers of Islamic and conventional banks to use IB. Meanwhile, before the Covid-19 pandemic, PU of Islamic banks does not affect the intention of customers, but PU affects the conventional banks before and during the Covid-19 pandemic. Furthermore, an insignificant relationship is found between TR (TR) and customer intention to use IB, which shows that customers still consider using IB as a risky platform. Thus, the current study can contribute to the management of Islamic banks and conventional banks to make policy strategies to improve IB technology socialization and innovation for customers.

The method used in this study is the quantitative method. The use of quantitative methods can limit the ability of current research to look more closely by clarifying more problems related to the intentions and behavior of Indonesian customers using IB. Therefore, future studies are suggested using quantitative and qualitative methods to get a more detailed explanation of the results of this study. This research concentrates on customers who have used IB in Islamic and conventional banks and does not include other types of customers who defer, oppose, and reject IB. However, studying such customers can help to have a further understanding of the main obstacles that hamper the acceptance of IB. Besides, this research focuses entirely on the customer perspective without any perspective of the bank. Therefore, this can be a limitation for this study as it does not give a comprehensive picture to clarify the 
main aspects related to the successful implementation and adoption of IB from both parties; customers and banks.

\section{References}

Abbad, M. M. (2013). E-banking in Jordan. Behaviour and Information Technology, 32(7), 681-694. https://doi.org/10.10 80/0144929X.2011.586725

Alalwan, A. A., Dwivedi, Y. K., Rana, N. P., \& Algharabat, R. (2018). Examining factors influencing Jordanian customers' intentions and adoption of Internet banking: Extending UTAUT2 with risk. Journal of Retailing and Consumer Services, 40(2017), 125-138. https://doi.org/10.1016/j.jretconser.2017.08.026

Aldás-Manzano, J., Lassala-Navarré, C., Ruiz-Mafé, C., \& SanzBlas, S. (2009). Key drivers of Internet banking services use. Online Information Review, 33(4), 672-695. https://doi. org/10.1108/14684520910985675

Altin Gumussoy, C. (2016). Usability guideline for banking software design. Computers in Human Behavior, 62, 277-285. https://doi.org/10.1016/j.chb.2016.04.001

Asni, K., Nasir, N., Yunus, M., \& Darsono, N. (2019). Analysis on Internet banking services in Indonesia: Impact of customer value to converting intention. Proceedings of the 1st Aceh Global Conference (AGC 2018), (pp.498-505). 17-18 October 2018, Banda Aceh, Indonesia. https://doi.org/10.2991/agc18.2019 .73

Baber, H. (2019). E-SERVQUAL and its impact on the performance of Islamic banks in Malaysia from the customer's perspective. Journal of Asian Finance, Economics and Business, 6(1), 169-175. https://doi.org/10.13106/jafeb.2019.vol6.no1.169

Bashir, I., \& Madhavaiah, C. (2014). Determinants of young consumers' intention to use Internet banking services in India. Vision: The Journal of Business Perspective, 18(3), 153-163. https://doi.org/10.1177/0972262914538369

Berthon, P. R., Pitt, L. F., Plangger, K., \& Shapiro, D. (2012). Marketing meets Web 2.0, social media, and creative consumers: Implications for international marketing strategy. Business Horizons, 55(3), 261-271. https://doi.org/10.1016/j. bushor.2012.01.007

Bhatt, R. (2011). Theory of planned behavior: A perspective in India's internet banking. International Journal of Management and Tourism, 19(2), 12-26.

Chan, K. H. (2001). Understanding adoption and continual usage behaviour towards Internet banking services in Hong Kong. Master thesis, Lingnan University, Hong Kong. Retrieved from https://commons.ln.edu.hk/cds_etd/5/

Chau, V. S., \& Ngai, L. W. L. C. (2010). The youth market for Internet banking services: Perceptions, attitude and behaviour. Journal of Services Marketing, 24(1), 42-60. https://doi. org/10.1108/08876041011017880

Chen, Q. L., \& Zhou, Z. H. (2016). Unusual formations of superoxo heptaoxomolybdates from peroxo molybdates.
Inorganic Chemistry Communications, 67(3), 95-98. https:// doi.org/10.1016/j.inoche.2016.03.015

Chin, W. W. (1998). The partial least squares approach for structural equation modeling. In: G. A. Marcoulides (Ed.), Modern methods for business research (pp. 295-336). Mahwah, NJ: Lawrence Erlbaum Associates.

Chiou, J. S., \& Shen, C. C. (2012). The antecedents of online financial service adoption: The impact of physical banking services on Internet banking acceptance. Behaviour and Information Technology, 31(9), 859-871. https://doi.org/10.10 80/0144929X.2010.549509

Davis, F. D., Bagozzi, R. P., \& Warshaw, P. R. (1989). User acceptance of computer technology: A comparison of two theoretical models. Management Science, 35(8), 982-1003. https://doi.org/10.1287/mnsc.35.8.982

Dijkstra, T. K., \& Henseler, J. (2015). Consistent and asymptotically normal PLS estimators for linear structural equations. Computational Statistics and Data Analysis, 81, 10-23. https:// doi.org/10.1016/j.csda.2014.07.008

Dwivedi, Y., \& Irani, Z. (2009). Understanding the adopters and non-adopters of broadband. Communications of the ACM, 52(1), 122-125. https://doi.org/10.1145/1435417.1435445

Fatimah, E. O., \& Suyanto, A. (2016). Analysis factors of using Internet banking in Indonesia. Management and Organizational Studies, 3(2), 10-15. https://doi.org/10.5430/mos.v3n2p10

Fishbein, M., \& Ajzen, I. (1975). Belief, attitude, intention, and behavior: An introduction to theory and research. Boston, MA: Addison-Wesley.

Fornell, C., \& Larcker, D. F. (1981). Evaluating structural equation models with unobservable variables and measurement error. Journal of Marketing Research, 18(1), 39. https://doi. org/10.2307/3151312

Gefen, D., Karahanna, E., \& Straub, D. W. (2015). Trust and tam in online shopping: an integrated model. Statewide Agricultural Land Use Baseline, 1(1), 51-90. https://doi.org/10.1017/ CBO9781107415324.004

Giovanis, A. N., Binioris, S., \& Polychronopoulos, G. (2012). An extension of TAM model with IDT and security/privacy risk in the adoption of Internet banking services in Greece. EuroMed Journal of Business, 7(1), 24-53. https://doi. org/10.1108/14502191211225365

Hair, J., Anderson, R., Tatham, R., \& Black, W. (1994). Multivariate Data Analysis with Readings. Englewood Cliffs, NJ: PrenticeHall.

Henseler, J., Dijkstra, T. K., Sarstedt, M., Ringle, C. M., Diamantopoulos, A., Straub, D. W., Ketchen, D. J., Hair, J. F., Hult, G. T. M., \& Calantone, R. J. (2014). Common beliefs and reality about PLS: Comments on Rönkkö and Evermann (2013). Organizational Research Methods, 17(2), 182-209. https://doi.org/10.1177/1094428114526928

Heryani, I. I. P., Simanjuntak, M., \& Maulana, A. (2020). Behavioral usage of internet banking as financial transaction tool. Journal 
Aplikasi Bisnis Dan Manajemen, 6(1), 86-95. https://doi. org/10.17358/jabm.6.1.86

Hu, L., \& Bentler, P. M. (1998). Fit indices in covariance structure modeling: Sensitivity to underparameterized model misspecification. Psychological Methods, 3(4), 424-453. https://doi.org/10.1037//1082-989x.3.4.424

Kalaiarasi, H., \& Srividya, V. (2013). An investigation on online banking adoption. International Journal of Business Innovation and Research, 7(1), 99-112. https://doi.org/10.1504/ IJBIR.2013.050558

Kaleem, A., \& Ahmad, S. (2010). Bankers perception towards Bai Salam method for agriculture financing in Pakistan. Journal of Financial Services Marketing, 15(3), 215-227. https://doi. org/10.1057/fsm.2010.18

Kaur, A., \& Malik, G. (2019). Examining factors influencing Indian customers' intentions and adoption of Internet banking: Extending TAM with electronic service quality. Innovative Marketing, 15(2), 42-57. https://doi.org/10.21511/ im.15(2).2019.04

Kesharwani, A., \& Tripathy, T. (2012). Dimensionality of perceived risk and its impact on internet banking adoption: An empirical investigation. Services Marketing Quarterly, 33(2), 177-193. https://doi.org/10.1080/15332969.2012.662461

Kholid, M. N. (2019). Determinants of intention to use Islamic mobile banking: Evidence from millennial generation. Jurnal Ekonomi \& Keuangan Islam, 5(2), 53-62. https://doi. org/10.20885/jeki.vol5.iss2.art2

Lada, S., Harvey Tanakinjal, G., \& Amin, H. (2009). Predicting intention to choose halal products using theory of reasoned action. International Journal of Islamic and Middle Eastern Finance and Management, 2(1), 66-76. https://doi. org/10.1108/17538390910946276

Lech, P. (2012). Information gathering during enterprise system selection: Insight from practice. Industrial Management and Data Systems, 112(6), 964-981. https://doi. org/10.1108/02635571211238545

Liao, C. H., Tsou, C. W., \& Huang, M. F. (2007). Factors influencing the usage of $3 \mathrm{G}$ mobile services in Taiwan. Online Information Review, 31(6), 759-774. https://doi. org/10.1108/14684520710841757

Lomoller, J. B. (1989). Latent Variable Path Modeling with Partial Least Squares. In: Physica: Heidelberg.

Makanyeza, C., \& Chikazhe, L. (2017). Mediators of the relationship between service quality and customer loyalty: Evidence from the banking sector in Zimbabwe. International Journal of Bank Marketing, 35(3), 540-556. https://doi.org/10.1108/IJBM-112016-0164

Martins, C., Oliveira, T., \& Popovič, A. (2014). Understanding the Internet banking adoption: A unified theory of acceptance and use of technology and perceived risk application. International Journal of Information Management, 34(1), 1-13. https://doi. org/10.1016/j.ijinfomgt.2013.06.002
Meuter, M. L., Bitner, M. J., Ostrom, A. L., \& Brown, S. W. (2005). Choosing among alternative service delivery modes: An investigation of customer trial of self-service technologies. Journal of Marketing, 69(2), 61-83. https://doi.org/10.1509/ jmkg.69.2.61.60759

Morgan, R. M., \& Hunt, S. D. (1994). The commitment-trust theory of relationship marketing. Journal of Marketing, 58(3), 20. https://doi.org/10.2307/1252308

Rahi, S., \& Abd-Ghani, M. (2019). Integration of expectation confirmation theory and self-determination theory in Internet banking continuance intention. Journal of Science and Technology Policy Management, 10(3), 533-550. https://doi. org/10.1108/JSTPM-06-2018-0057

Rahi, S., \& Abd-Ghani, M. (2016). Customer's perception of public relation in e-commerce and its impact on e-loyalty with brand image and switching cost. Journal of Internet Banking and Commerce, 21(3).

Ringle, C. M., Wende, S., \& Becker, J. . (2015). SmartPLS 3. SmartPLS GmbH.

Ronny. (2018). Customer participation in the creation and implementation of the service for Internet banking. Journal of Economics, Business \& Accountancy Ventura, 20(3), 309-317. https://doi.org/10.14414/jebav.v20i3.763

Shahzad, F., Xiu, G. Y., \& Shahbaz, M. (2017). Organizational culture and innovation performance in Pakistan's software industry. Technology in Society, 51, 66-73. https://doi. org/10.1016/j.techsoc.2017.08.002

Sharma, R., Singh, G., \& Sharma, S. (2020). Modelling Internet banking adoption in Fiji: A developing country perspective. International Journal of Information Management, 53(June 2019), 102116. https://doi.org/10.1016/j.ijinfomgt.2020.102116

Simintiras, A. C., Dwivedi, Y. K., \& Rana, N. P. (2014). Can marketing strategies enhance the adoption of electronic government initiatives? International Journal of Electronic Government Research, 10(2), 1-7. https://doi.org/10.4018/ ijegr.2014040101

Sitorus, H. M., Govindaraju, R., I, I., Wiratmadja, \& Sudirman, I. (2017). Examining the role of usability, compatibility and social influence in mobile banking adoption in Indonesia. Journal of Chemical Information and Modeling, 53(9), 16891699. https://doi.org/10.1017/CBO9781107415324.004

Tabash, M. I., Albugami, M. A., Salim, M., \& Akhtar, A. (2019). Service quality dimensions of E-retailing of Islamic banks and its impact on customer satisfaction: An empirical investigation of Kingdom of Saudi Arabia. Journal of Asian Finance, Economics and Business, 6(3), 225-234. https://doi. org/10.13106/jafeb.2019.vol6.no3.225

Taib, F. M., Ramayah, T., \& Abdul Razak, D. (2008). Factors influencing intention to use diminishing partnership home financing. International Journal of Islamic and Middle Eastern Finance and Management, 1(3), 235-248. https://doi. org/10.1108/17538390810901168 
Usman, H. (2015). Customers trust on Islamic Banks in Indonesia. Journal of Asian Finance, Economics and Business, 2(1), 5-13. https://doi.org/10.13106/jafeb.2015.vol2.no1.5.

Varaprasad, G., Sridharan, R., \& Unnithan, A. B. (2013). Internet banking adoption in a developing country: An empirical study. International Journal of Services and Operations Management, 14(1), 54-66. https://doi.org/10.1504/IJSOM.2013.050561

Vukovic, M., Pivac, S., \& Kundid, D. (2019). Technology acceptance model for the Internet banking acceptance in split. Business Systems Research, 10(2), 124-140. https://doi. org/10.2478/bsrj-2019-022
We are Social. (2020), Digital in 2020. Retrieved from https:// datareportal.com/reports/digital-2020-indonesia.

Yuan, S., Liu, Y., Yao, R., \& Liu, J. (2016). An investigation of users' continuance intention towards mobile banking in China. Information Development, 32(1), 20-34. https://doi. org/10.1177/0266666914522140

Yudha, H. N., Prof, J., \& Sh, S. (2015). Analysis Of The Effect Of Bank Customer Perception On The Internet Banking Adoption. Diponegoro Journal of Accounting, 4(4), 1-15. 